\title{
カーボンナノチューブ充てんゴムの卓越した 特性とその応用
}

\author{
野口 徹* ${ }^{1} \cdot$ 植木 宏之 ${ }^{1} \cdot$ 犬飼 茂樹 $^{1}$. \\ 新原 健一 ${ }^{1} \cdot$ 伊藤 正栄 $^{2} \cdot$ 竹内 健司 $^{3} \cdot$ 遠藤 守信 $^{3}$

\section{Various Advanced Properties and Applications of Carbon Nanotubes/Rubber Composites}

Toru NOGUCHI ${ }^{*}$, Hiroyuki UEKI ${ }^{1}$, Shigeki INUKAI ${ }^{1}$, Kenichi NIIHARA $^{1}$, Masaei ITO ${ }^{2}$, Kenji TAKEUCHI ${ }^{3}$, Morinobu ENDO $^{3}\left({ }^{* 1}\right.$ :Research Center for Exotic Nano Carbon Project, Shinshu University, 4-17-1 Wakasato, Nagano-city, Nagano 380-8553, Japan, Development Center Nagano, Nissin Kogyo Co., Ltd. , Kazawa 801, Toumi-city, Nagano 3890514, Japan. ${ }^{2}$ Schlumberger KK, 2-2-1 Fuchinobe, Sagamihara, Kanagawa 229-0006, Japan. ${ }^{3}$ Institute of Carbon Science and Technology, Shinshu University, 4-17-1 Wakasato, Nagano-city, Nagano 380-8553, Japan)

Hydrocarbons such as oil and gas are critical resources for the functioning of human societies. Today, with the dearth of easy-to-reach reservoirs, the oil and gas industry is conducting more of its exploration and exploitation activities in difficult-to-reach and harsh environments. Key challenges in exploiting these new reservoirs include extremely high temperatures and pressures. The rubber composites obtained from the carbon nanotubes cellulation technology increases operational ratings from $175{ }^{\circ} \mathrm{C}$ and $140 \mathrm{MPa}$ to $260{ }^{\circ} \mathrm{C}$ and $240 \mathrm{MPa}$ for deeper, hotter conditions, and it is especially appropriate for deepwater reservoirs. We believe that our development of the sealing material to enhance oil recovery from deep, hot reservoirs may help double the R/P ratio. The cellulation technologies can be applied to various matrix composites such as metals, ceramics, and other polymers.

Key Words : Carbon Nanotubes, Rubber Matrix Composite, Cellulation, Filler

\section{1. は じ め に}

\section{1. カーボンナノチューブ複合材料}

最近，著者らが開発し商品化した超過酷環境下で使用さ れるシール材が二つの意味で世界的に注目されている ${ }^{11}$. 一つは，カーボンナノチューブ（CNT）が多量に使用さ れる複合材料分野で初めての大きな成果であること，つま り，CNTがようやくその優れた特徴を発揮して本格的に 応用への道が開かれたこと。第二に, CNTで補強したフ ッ素ゴム（FKM）で作ったシール材が石油業界に革命的 な影響を及ぼす可能性が出てきたことである.

1976年に遠藤ら ${ }^{2.3)}$ が始めてCCVD法でCNTを合成し， 飯島 ${ }^{4)}$ が1991年にその構造を世に知らしめて以来, CNT はフラーレン 5) とともに, ナノカーボンの中心的素材と して注目を集めてきた。その特殊な構造と優れた性質は, 多数の論文とともに前報1)に示したのでここでは省略す るが, 数 $\mathrm{nm}$ から数十 $\mathrm{nm}$ と言う極めて細くて長いチュー ブ状の繊維であるCNTは，束状のバンドル，また互いに
複雑に絡み合った凝集体であるため, CNT1本1本の特性, さらにはCNTが形成するナノ空間構造を制御，利用する ことが極めて困難であるため，その固有の優れた特徴を複 合材料として発現することが出来なかった ${ }^{6,7)}$. さらに, 高コストも相乗要因であろう。この性能発現の問題は, エ ラストマー・ゴム類 ${ }^{1,8)}$ ，および樹脂，金属 ${ }^{9,10)}$ ，七ラミッ クス ${ }^{11)}$ の一部については著者らが，ほぼ克服し，CNT1 本 1 本が分離した後形成する立体構造をセルレーションと 名づけて報告してきた。ここでは, 石油探査·生産で威力 を発揮した複合材料の開発を中心にCNTを用いたゴムシ ール材の革新について概説する。

\section{2. 複合材料の石油分野などへの応用}

わが国でゴムシール材が石油業界に革命をもたらすかも しれないと言うのは誰も想像できないに違いない，何故な ら, 日本は石油を輸入するだけで, 生産していないため最 も重要な資源である石油の探査·生産について全くの素人 であるためと思われる．にもかかわらず，人類はエネルギ 一以外に, 工業の原材料, 農業の肥料・農薬なども石油に 
頼っているので，いかに石油の枯渇年数を延ばすかは人類 共通の課題でさえある。著者らのグループがマルチウォー ルカーボンナノチューブ（MWCNT）を充てんしたフッ 素ゴム（FKM）を用いて，現在の石油開発技術の耐熱性 を $175^{\circ} \mathrm{C}$ から $260{ }^{\circ} \mathrm{C}$ に, 耐圧性を $140 \mathrm{MPa}$ から $240 \mathrm{MPa}$ に, さらに耐ガス性なども飛躍させ，これは地下埋蔵量の約 $1 / 3$ (可採率) しか取り出せない ${ }^{12,13)}$ 石油の供給能力を, 殆どの油層から生産できる可能性を示したことになる。即 座にUSAの広報に紹介され，全世界に大きな驚きを与え た. 石油可採率の増大の歴史は，地下，または海底のさら に地下深く，つまり，高温·高圧領域，さらに，様々な高 温高圧の液体，ガスへの挑戦の歴史である．超音波，レー ダー，地震波その他各種の 10 種類以上のセンサーで探査 しながら，石油は最も効率よく生産されるが，これらの電 子・電気部品や精密メ力部品は超過酷環境下では全く弱い ので完璧に守るシール機構が不可欠であり，従って使用圧 力と温度の限界はシールによって決められることになる. つまり，今回開発したMWCNT/ゴム複合材料を用いたシ ール材は，使用環境の温度，圧力，および耐液体性，耐ガ ス性を飛躍的に革新した。現在まで，実際に既に 200 以上 の油田で実機評価されて好成績を収め，さらに評価が広が っている.さらに，各種のシール材を調べた結果，配管機 材，自動車ブレーキ用シール材などに用いると，耐磨耗性， 耐疲労性などの物理的強度と, 耐酸, 耐アルカリ性などの 化学的強度がいずれも向上するシール材が得られて一気に システムがパラダイムシフトする可能性が出てきた。この ような驚くべきゴム材料の MWCNTによる大幅な変化は, MWCNTと界面相で形成する立体構造，セルレーション によると提案している ${ }^{1,8)}$ 。本稿では，MWCNT/ゴム複合
材料の特徵的な性質をいくつか説明し，それを活用して成 功しつつある応用について概説する. また, 開発者として 不可欠な安全性についても，簡単に説明したい。

$$
\text { 2. カーボンナノチューブ・セルレーションとは }
$$

フィラー系複合材料に共通する重要因子は，フィラーの 均一分散と母材との濡れである. 均一分散体が最強の複合 材料を造るかは別問題として，まず，CNTのバンドルや 凝集体を解してCNTを1本1本に分離させることが始まり であることに違いない。図1にMWCNT（16wt％）充て ん EPDM複合材料の通常混練法により作成した試料の引 張破断面のSEM像（a）を示した. EPDM は非極性かつ 弾性に乏しいためCNT凝集粉を解繊するのが困難なポリ マーの一つである. 数 10 から $100 \mu \mathrm{m}$ 程度の大きさの白 く見えるMWCNTの凝集塊を島とする海一島構造がはっ きりと見える。この状態ではMWCNTの効果も出なけれ ば, 凝集塊が欠陥となって引張強さなども大きくばらつき, もちろん，耐熱性などの向上もない．何も考えずに作れば このようになる. そこで, 均一に分散させる手法が長年研 究されてきた。一例を示すと, EPDMをシクロへキサン に溶解した後MWCNTを攪拌混合し, 超音波混合し乾燥 した後ロール混合した試料が（b）である。ここでは海－ 島構造は観察されず，一見，均一分散体に見えるが，拡大 した（b）図で分かるように，サブミクロンから数ミクロ ンの凝集体が観察される。MWCNT凝集粉は細かく粉砕 されただけで，解繊され均一分散したわけではないことが 分かり，これでは期待したほどの効果が得られないなのは Bokobzaの総説 ${ }^{7)}$ にも詳しい. 強力ボールミルなどによ る混合も同様の結果である.とにかく，無理やり大きな力

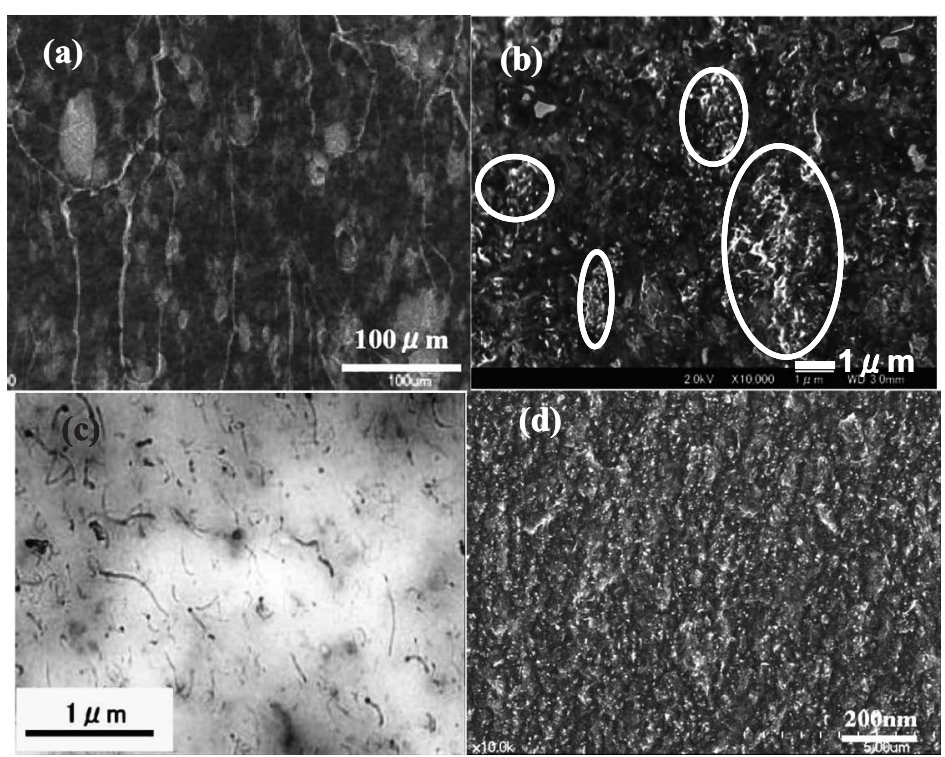

図1 EPDM 中への MWCNT の分散：通常混練法試料の引張破断面 SEM 像 (a)，溶液超音波混合後混練した試料の引張破断面 SEM像（b)，弾性混 練法に試料の薄片の TEM 像 (c), 引張破断面 SEM 像 (d) 
だけでかき混ぜても解繊は出来ないことが分かる.そこで, 著者らは大きなせん弾力は必要であるが，無理やりかき混 ぜるのではなく，解繊の原理に従った加工法を取ることが 出来れば，MWCNTは混合時に自然に解繊され，系の工 ントロピーが大きくなるような構造に到達すると考えてい る。すなわち，MWCNT凝集粉の空隙にポリマーが進入 可能な粘性 (流動性), MWCNTとポリマーの濡れ, そし て最後に大きなせん弾力を加えて弾性変形と復元を繰り返 し与えることである。これらを総称して「弾性混練 法1（8）,14)」と名付けたが，これは，ゴム専門家以外での 説明に用いたのであって，ゴムの専門家から見れば当たり 前と思われるかもしれない。前報 ${ }^{14)}$ で示したように， EPDM は濡れにくいので $100{ }^{\circ} \mathrm{C}$ 以上の高温で混練して分子 鎖を適度に切断してフリーラジカルを生成させた状態で MWCNTを混合し，直ちに低温に保ったロールで大きな せん弾力を与えた試料の引張破断面が（d）図で MWCNT16 wt\%であり，（c）図のTEM像は見易くする ためにMWCNT3 wt\%である.MWCNTは1本1本分離さ れ分布することが分かる。3D-TEMで調べた結果では， MWCNT 同士はほとんど接触せず，1〜2 nm離れた界面 相を挟んでの存在が多いことが分かっている．以上のよう な分散・分布状態の違いは意外なところ，パルスNMRの スピンースピン緩和時間 $\mathrm{T} 2$ に現れて著者らが国内外での 特許登録に貢献した。図 2 にRマトリックスを例とした パルス法NMRハーンエコー法で測定した網目鎖成分の $150{ }^{\circ} \mathrm{C}$ のスピンースピン緩和時間 $\mathrm{T} 2 \mathrm{n}$ とフィー充てん率 の関係を示した．架橋により大きく $\mathrm{T} 2$ が変化するので， ここではフィラーの影響を直接比較するために，測定には 無架橋体試料を用いた. 比較として示したHAFカーボン ブラックは充てん率が増大すると $\mathrm{T} 2 \mathrm{n}$ は長くなり多量充 てんでは低下するがマトリックスより短くならなかった。 一方，MWCNT系は直径が細いほどT2n は低下の程度が 大きくなり，これは，EPDM，NBR，FKMその他のポリ マー系でも同様の傾向が見られた。これら $\mathrm{T} 2 \mathrm{n}$ の低下は

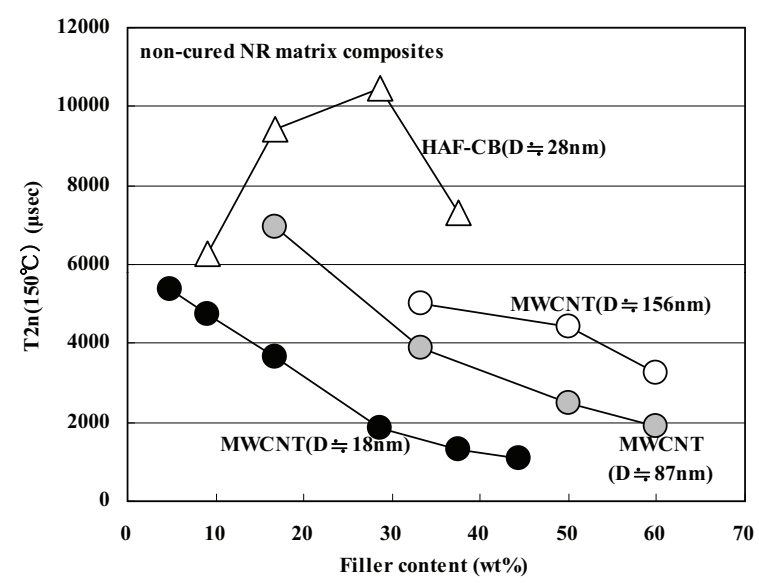

図2 NRマトリックス複合材料のスピンースピン緩和時間 $\mathrm{T} 2 \mathrm{n}$ (網目鎖の $\mathrm{T} 2$ ）
ゴム相のエントロピーの低下によると推定され，これはフ イラーに拘束された界面相，ゴム相などのエントロピーが 低下するためと考えられる。しかし，HAFブラックでも $\mathrm{HAF}$ 同士の距離はナノメートルサイズで非常に小さく, また，バウンドラバーと呼ばれる界面相が形成されること も周知であるにもかかわらず $\mathrm{T} 2 \mathrm{n}$ が低下しないのは，マ トリックスのゴム相は自由な連続相をなしているためカー ボンブラックの拘束力が及ばない領域が大きいためと思わ れる．MWCNT系はその大きなアスペクト比ゆえに複雑 な立体構造を形成し，マトリックスゴム相を取り囲んで拘 束することによってゴム相のエントロピーが低下すると考 えられる。もちろん，分散不良の図 1 の（a）（b）では $\mathrm{T} 2 \mathrm{n}$ の低下は見られなかった。これらのデータが著者らの 特許を成立させ，またセルレーションを提唱するきっかけ となったデータの一つである. 以上のように，アスペクト 比の大きいナノスケール繊維のゴム中で作る立体構造が $\mathrm{T} 2 \mathrm{n}$ を低下させた要因であると考えられ，この構造体を形 成する現象をセルレーションと名付け，模式的に図 3 に示 した ${ }^{8)}$ 。まず解繊が始まると 1 本 1 本分離した CNTに界面 相が形成され（a），ある濃度（1 wt \% 程度と推定）で CNTの連鎖が形成され（b)，電気が流れるようになるの はパーコレーションとして有名である。しかし，このよう な低濃度では物性の変化は小さく，濃度が増大した 10 $20 \mathrm{wt} \%$ の濃度で立体セル構造が部分的に形成され物性 が大きく変化し始め, 高濃度（c）に至って立体セル構造 が出来上がるとともに飛躍的な物性変化が発現する. 先に 示した通りゴム相のエントロピーは低下する傾向にある が，セルレーションによりCNTのエントロピーが増大し，

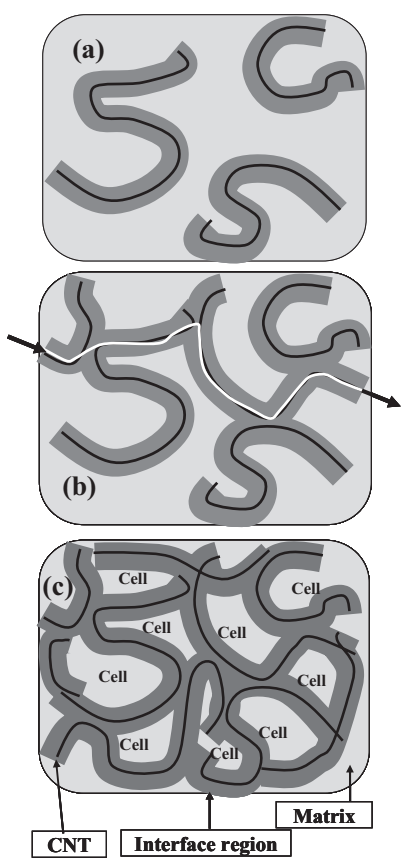

図3 セルレーションモデル：解繊と界面相形成 (a), 連鎖形成パー コレーション（b)，立体構造形成セルレーション（c) 
系全体としてエントロピーは増大したと思われるが，これ らの物理学的理論解明と記述については著者らの共同研究 グループで進めており，さらに進化した理論も出始めてい るので，今後報告していきたい。なお，ダブルウォールナ ノチューブ (DWNT) や10nm 級 CNT とカーボンブラッ クなどのナノ粒子の混合系では数 wt\%の低濃度でのセル 形成が可能で，強い補強と興味深い挙動が見られるが，こ れは次報にて報告する。

\section{MWCNT/FKM シール材の開発と資源探査·生産への応用}

石油業界では5，6年前にCNTを用いた複合材料による 各種部品の高性能化, 高機能化に世界的に取り組んだ結果, 全て失敗に終わった苦い経験を有していた，従って，本開 発当社から後ろ向きの意見も強かったが，それだけに，本 開発に貢献したセルレーション（仮説）の効果は大きい. 何故なら，飛躍的な物性向上のための理論的な原理を提唱 したからこそ，世界中の石油探査，採掘の技術開発関係者 が日本の技術に尊敬を持って，再びCNT応用に積極的に 協力したのが大きな成功に結びついたことは間違いない。 技術開発の内容は前報 ${ }^{1)}$ に詳述されているので，一部の データについて示す。図 4 に耐圧・耐熱性を示した。これ は，表面処理によってマトリックスとの接着を劇的に向上 させた MWCNTとFKM，さらに，カーボンブラックの混 合系によってO-ring を作成し，行った短期耐圧試験（20 分間のリークを調べる）の結果である。今回の開発品は， 現在油田で使用されている現行FKMに比べて全温度域で $10 \mathrm{kpsi}$ (約700気圧) 耐圧性が高く, 特に，175 ${ }^{\circ} \mathrm{C}$ 以上の 超高温で耐圧性が低下しないのが特徵である。MWCNT をカーボンブラックに置き換えたControl 品は現行 FKM とほとんど変わらなかった。油田では，175 ${ }^{\circ} \mathrm{C} ・ 1,400$ 気 圧が標準であるが，今回開発したシール材は $260{ }^{\circ} \mathrm{C}$ 以上で の耐久試験でも現状条件での使用時間の 2 倍以上と優れて いる，既に行われている油田でのフィールドテストでは，

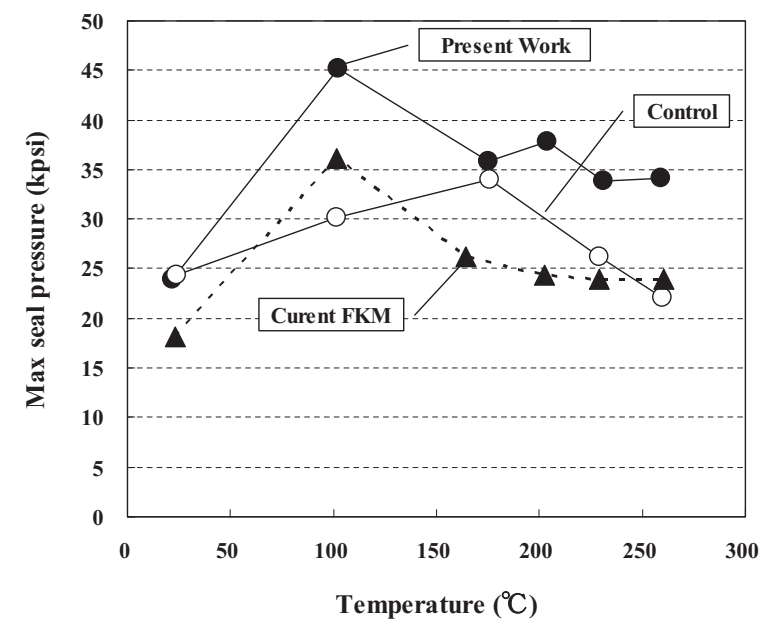

図4 MWCNT/FKM 複合材料にて作成したO-ring の耐圧-耐熱特性
$0{ }^{\circ} \mathrm{C}$ 付近の低温から $260{ }^{\circ} \mathrm{C}$ の高温まで, 2,400 気圧の圧力 に耐え, 様々な高温の液体, ガスに耐えて成功を収め, さ らに200以上の油田に広がってきている。このシール機構 の高性能化は, その中で守られる電子部品, 精密メ力部品 の高温度化も急速に促しており，石油開発の革命と言われ 始めている所以である。ただし，今回成功した開発品はス タティックシールであり，これよりさらに格段に難度が高 いダイナミックシールの開発を経済産業省やJST の支援 を得て取り組んでいる。このように革新的な特性を有する シール材の耐熱性, 高温特性を調べるため, 空気中で線膨 張係数を測定し， $1{ }^{\circ} \mathrm{C}$ おき微分した特性を図 5 に示した. 上段が無架橋試料，下段が架橋試料である。

無架橋系の場合，FKM単独（0\%）から $9 \mathrm{wt} \%$ かで0 ${ }^{\circ} \mathrm{C}$ から室温付近で流動による急激な膨張が見られた。これ は，試料寸法を正確に測定するため $25 \mathrm{kPa}$ の非常に小さ い負荷をかけながら寸法を測定している関係上，流動し始 めると急激な膨張となって現れるためである。11 wt\%系 では一旦澎張するが安定化し（微分值ではピークとなる）, 16，26 wt\%では低温から高温まで線膨張係数が小さい安 定した熱膨張を示し, 特に, $350{ }^{\circ} \mathrm{C}$ の超高温でも安定して いる.これらの挙動は, 明らかに $11 \mathrm{wt} \%$ 16 wt\%を境と する臨界現象と考えられ，高濃度側で異なる構造に転移し たことを示唆している.

架橋系では図が複雑になるので選択して図示したが，5
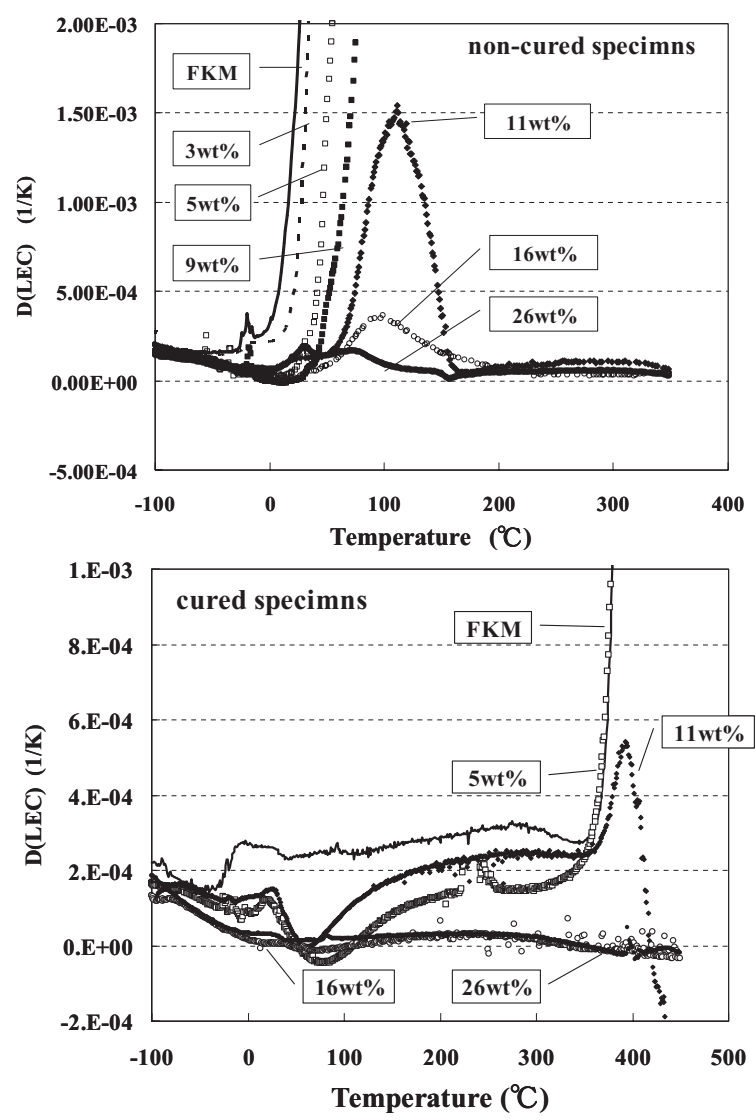

図 $5 \mathrm{MWCNT} / \mathrm{FKM}$ 複合材料の線澎張係数の微分值 (D (LEC) ) 
$\mathrm{wt} \%$ 以下では $340{ }^{\circ} \mathrm{C}$ 付近から急激に膨張の立ち上がりが認 められ，これは，無架橋系の流動現象ではなく軟化現象で, 当然，脱フッ素や脱フッ化水素を伴う．ところが，無架橋 系と類似して，11 wt\%で分子鎖切断が抑制され， $16 \mathrm{wt} \%$ 以上では $450{ }^{\circ} \mathrm{C}$ まで安定して分解が見られなかった。この ように架橋系でも臨界現象が認められ，これは本質的に無 架橋系で見られた現象と同じ構造変化と思われ，前報の

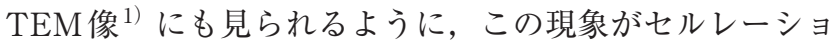
ンである.これらの構造変化の TEM 観察の詳細は, 現在, 論文投稿中である．これら，セル化した材料は極めて安定 した高温特性と高い耐熱性を有することが分かる.ただし， 線膨張係数の测定は分速 $10{ }^{\circ} \mathrm{C}$ の昇温で測定した結果であ るので，長期に熱劣化が全く起こらないと言う意味ではな いので誤解しないで頂きたい.

ここで，セルレーションによる耐熱性の飛躍的向上の原 因について少し考察する。通常のカーボンブラックによる 補強は，マトリックスゴムが連続相を成し，図2に示した ようにカーボンブラックの拘束効果によりエントロピーが 低下していない。また，ゴム相の酸化劣化が始まると連続 相であるため自動的に進行して止めようがない。一方， CNT系は太さにもよるが，マトリックスゴム相の拘束効 果が非常に大きいことが図 2 から分かる。これは，酸化を 受けてもゴム相はセル化によって小さく分断されているた め酸化が進行しにくく，また，ゴム相自身の分子運動性が 低下しているため, 酸化劣化し難くなっていると推定して いる。また，酸素の通過パスが長くなり，結果的に酸素拡 散が抑制されたと推定している。これ以外にも，CNTの 表面の活性度，活性サイトの種類，数などで，耐熱性，耐 薬品性が大きく異なることが分かってきている，つまり， 物理的にはセル構造によるゴム相のエントロピーの低下, 酸素の拡散阻害また，化学的にはCNT 表面の反応性の制 御によって，高温での安定性や高い耐熱性が得られている と考えられる。なお，油田での実証デー夕も加えて近く論 文として発表する予定である。

\section{4. その 他 の 応 用}

\section{1. アルミニウム複合材料の開発}

著者らが最初に材料開発に成功したのが $\mathrm{Al}$ マトリック ス複合材料である.NEDOプロジェクトとして行われた 本開発は, 当時, 東京工業大学の西敏夫教授, 中嶋健助手, 愛知工業大学の山田英介教授, 京都工芸繊維大学の陣内浩 司准教授，岡山県工業技術センターの永田員也室長らの全 面的協力を得て，世界で始めて実用レベルの高度補強 $\mathrm{Al}$ 複合材料の作成に成功した事例としてよく知られている. 代表例である試料の引張強さ $400 \mathrm{MPa}$ は純 $\mathrm{Al}$ としては先 例 ${ }^{15)}$ に比べても極めて高く，使用可能温度 $400{ }^{\circ} \mathrm{C}$ は $\mathrm{Al}$ と しては極めて高い。その他，放熱性，耐食性などにバラン
スの取れた素材である.図6にこの材料の後加工の効果を 示した。冷間加工によって $0.2 \%$ 耐力（実用上の強度）が $320 \mathrm{MPa}$ から $520 \mathrm{MPa}$ に増大し，さらに溶体化処理を加え ることで $700 \mathrm{MPa}$ 近くにまで増大した。これは高張力鋼に も匹敵する。もちろん比重は $\mathrm{Al}$ の 2.7 のままであり，これ らの性質を活かした開発を現在も NEDOプロジェクトで 行っている.

\section{2. セラミックス複合材料}

セラミックスは汎用に大量に使用されているアルミナ, 強度，耐熱性に優れる $\mathrm{SiC}$ を心に高じん性化を目指して いる。一時ファインセラミックスが一世を風靡した時代が あったが，その名残ははなはだ寂しいのは周知の通りであ る.その原因として，七ラミックスは脆い，という根源的 な欠点を克服できなかったためではないかと推測してい る。ここでは，著者らの共同研究者である東北大学の川崎 亮研究室の論文を紹介したい。強酸で処理したMWCNT 原料粉とアルミナ粉を水媒中で $\mathrm{pH}$ を調整しながら擋拌す るとMWCNTは解繊され，これを乾燥してSPS焼結して 破壊じん性值を求めたところおよそ 7 と言う值が得られ, これはアルミナ $3.5 〜 40$ のよそ70\%アップである ${ }^{11)}$. 著 者らが再現とスケールアップをかねて $100 \mathrm{~g}$ 級で試料を作 成して評価したところ，チャンピオンデータで破壊じん性 值 9.8 という 10 近い值が得られ，これは鋳鉄に匹敵するも のである。この破壊じん性值アップのメカニズムは， MWCNTによる破壊進行の阻害，MWCNTによるブリッ ジ効果など色々と考えているが現在詳しく調査中である.

一方， $\mathrm{SiC}$ は焼結が難しく難航していたが，最近ようや く焼結条件を把握して曲げ強度の増大などのデータが出つ つある.今後, 破壊じん性值の大幅なアップを目指したい。

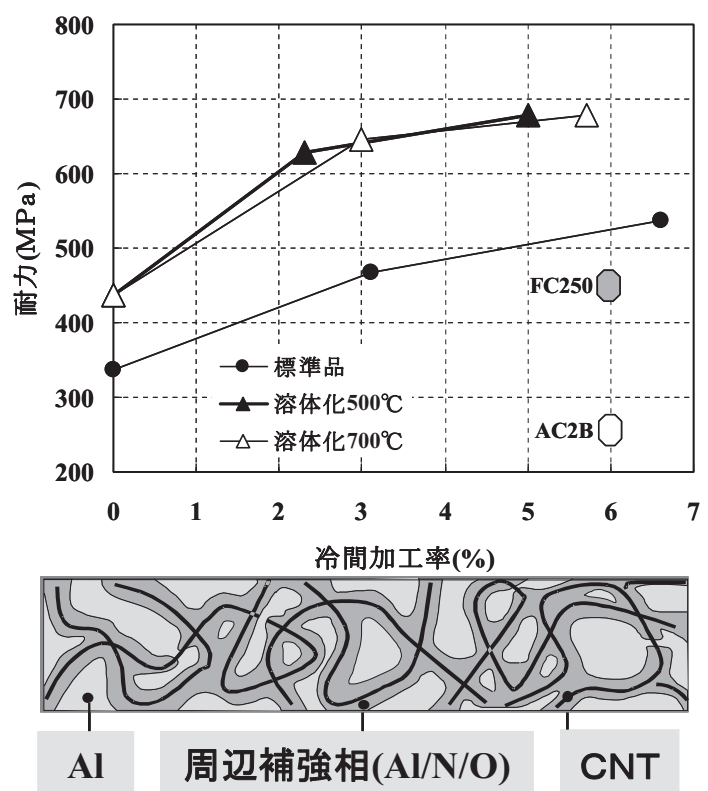

図6 MWCNT (1.2vol\%) / $\mathrm{Al}$ の耐力と後加工の効果 


\section{3. 樹脂系複合材料}

人工関節に用いられる超高分子量ポリエチレン (UHMW-PE) の耐磨耗性改善による永久使用可能な人工 関節の開発をNEDOプロジェクトで行った。現在，論文 投稿中であるので，詳細は省略する。一般に，樹脂では弾 性混練法が非常に困難であるが，UHMW-PEは $200{ }^{\circ} \mathrm{C}$ 以上 にて弾性領域を有し，また，160〜 $200{ }^{\circ} \mathrm{C}$ 付近で融解した 表面の弾性混練が可能なことを見出し，MWCNTセルレ ーションによって磨耗耐久性 5 倍以上という成果を得てい る。これは，実使用上ほとんど磨耗しないレベルである.

また，他の樹脂系への展開は，それぞれの樹脂に弾性混 練領域を見出してMWCNTでセル化することが成功への 道と思われる。

\section{5. 実用化と課 題}

\section{1. 実用化の課題}

運営面では, 研究開発資金の調達, 適切なコンソーシア ム形成と円滑な運営などがある．著者らの企業グループが 束になってもかなわない目標もあるので，経済産業省，文 部科学省の大きな支援を期待したい.

CNTの問題としては，安全性とコストである。コスト については最近かなり下がってきている。一昔前なら $\mathrm{g}$ 単 位であったものが，直径などにもよるが，3万円 $/ \mathrm{kg}$ 程 度のものが多くなり, さらに，数千円 $/ \mathrm{kg}$ 程度のCNTも 現れている。ただし，純度や，欠陥，安全性に留意する必 要がある。しかし，それでもフィラーとしては高価なこと に代わりはない，そこで，著者らは，相当の価格アップも 受け入れられる飛躍的な革新技術の開発に注力している. 資源開発，新エネルギー分野，誰も解決できない環境材料 分野，医療などの付加価值の非常に高い分野に挑戦してい くことが重要である.

また，将来的に大きなコストダウンを果たすには，七ル レーションの理論解明とさらなる進化した理論構築が必要 と考えている．原理の追求と新しい原理の開拓は，新しい 特性の発現とコストダウンへの道を示すことにつながるか らである。現在，信州大学を中心に新しい原理も追及して いるので，お目にかける日も近いと考える.

CNT 最後の課題は安全性である。個人的には，もっと 危険な粉体やガスはたくさんあると思われるが，人類が多 量に使ったことの無いのがナノマテリアルであるので，万 全の配慮を持って望みたい。特に，複合材料はCNTを最 も多量に用いる品物であるため, 商品試作などを始めれば CNT10kg 単位で続々と試作していくことになる.

この場合，リスク＝ハザード×暴露量 の考え方が基本 である.ハザードは毒性の程度と言い換えてもよく，まず， この毒性，つまり発がん性の程度をはっきりさせることで ある。同時並行で，最大許容暴露量（OEL）を求めるこ とが必要である。さらに，環境中の CNT飛散量（暴露量）
を測定することも重要である. 著者らは実験室, 試作工場, 量産工場ともに, 各工程ごとに粉塵量, ナノ粉体量, カー ボン量，CNT量などを連続計測しながら，厳しい取り扱 い方法によって，リスク＝ゼロを達成している。 ビジネス としては, 安全管理, リスクマネージメントが鍵を握って いる.

\section{2. 実用化の期待}

最近，半導体製造用の樹脂製品の帯電防止用途に期待さ れ，一部実際に用いられているが，当初予想した量を大幅 に下回りそうで, $\max 100$ トン, 現状50トン以下と推定さ れる. 1〜 $3 \mathrm{wt} \%$ 小量配合するが樹脂の物性低下の問題と ケッチェンブラックとのコスト競争のためと思われる。そ の他，実用化間近と言われながら中々正体を現さないエポ キシ樹脂補強, 新しい電池用途など, 何らかの課題を有し ていると推定される.

一方，著者らが開発した複合材料，シール材，シール機 構, および利用製品は非常に幅広く発展する. 油田での成 功を始まりとして，さらに資源分野で大きく拡大し，他の 資源開発，航空宇宙分野，過酷使用用途の化学工場など展 開が広い。さらに難易度の高いダイナミックシールが成功 に近づいており，これは，資源探査だけでなく，燃料電池， 医療用などのコンプレッサー，ポンプなど，配管機材，自 動車の過酷使用用途などの分野に大きな市場を持ってい る.

シール材以外では，前述の通り，著者らのグループは， 高じん性セラミックス，高強力 $\mathrm{Al}$ など軽金属，金属に代 わる高剛性樹脂など，その分野の革新を促す実用化を進め ている.また, 純国産超低炭素エネルギー地熱マグマ発電, 漏水ゼロシステムおよび新浄水・海淡化技術開発なども実 際に研究開発を始めている. $\mathrm{Al}$ の4.1.項で示した共同研究 者はもちろん，現在では 7 大学，3病院，企業約 30 社，そ れぞれが課題を乗り越え実用化を目指して精力的に取り組 んでいる。なお，これら研究は，JSTエキゾチック・ナノ カーボンの創成と応用プロジェクト拠点 (信州大学) を軸 に，経済産業省関東経済産業局，中部経済産業局，NEDO の皆様の支援により実施している。

\section{References}

1 ) Endo, M.; Noguchi, T.; Ito, M.; Takeuchi, K.; Hayashi, T.; Kim, Y. A.; Wanibuchi, T.; Jinnai, H.; Trrones, M.; Dresselhaus, M. S.: Adv. Funct. Mater., 18, 3403 (2008)

2 ) Oberlin, A.; Endo, M.; Koyama,T.: J. Crstal Growth., 32, 335 (1976)

3 ) Endo, M.: Chem. Tech.,18, 568 (1988)

4 ) Iijima, S.: Nature, 354, 56 (1991)

5 ) Kroto, H.W.; Heath, J.R.; O'Brien, S.C.; Curl,R.F.; Smalley,R.E.: Nature, 318, 354 (1985)

6 ) Lau, K-T.; Hui D.: Composites. PartB. Engng., 33B, 263 (2002)

7 ) Bokabza, L.: Polymer, 48, 4907 (2007)

8 ) Noguchi, T.; Inukai, S.; Ueki, H.; Magario, A.; Endo, M.; SAE 
Tech. Pap. Ser. (Soc. Automot. Eng), Page. 5P (2009)

9 ) Noguchi, T.; Magario, A.; Fukazawa, S.; Shimizu, S.; Beppu, J.; Seki, M.: Mater. Trans., 45, 602 (2004)

10) Kwon, H.; Takagi, K.; Miyazaki, T.; Kawasaki, A.: Carbon, 47, 570 (2009)

11) Estili, M.; Kawasaki, A.; Sakamoto, H.; Mkuchi, Y.; Kuno, M.; Tsukada, T.: Acta Materialia, 56, 4070 (2008)

12) Payne, M. L.; Pattillo, P.D.; Miller, R. A.; Jonson, C. K.: International Petroleum Technology Conference, (2007) , IPTC, 11463

13) Paula, Jr. R. R.; Ribeiro, P. R.; Santos, O. L. A.; SPE/IADC Drilling Conference and Exhibition, (2009), SPE/IADC, 119909
14) Iwabuki, H.; Noguchi, T.; Takeuchi, K.; Endo, M.: Nippon Gomu Kyokaishi, 82, 209 (2009)

15) Kuzumaki, T.; Miyazawa, K.; Ichinose, H.; Ito, K.: J.Mater.Res., 13, 2445 (1998)

\section{日本語表記参考文献}

14）岩蕗仁，野口徹，竹内健司，遠藤守信：日本ゴム協会誌，82, 209 (2009)

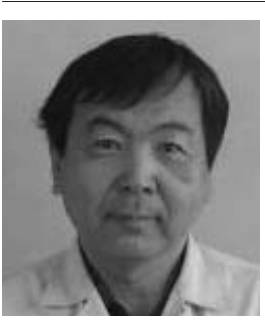

野口 徹; 日信工業(侏), 信州大学兼務：日信 工業侏開発本部 - 上席主幹（ $\mathrm{T} 386-8567$ 上田 市常田3-15-1 信州大学繊維学部内 AREC15研 究室), 信州大学エキゾチック・ナノカーボン の創成と応用プロジェクト拠点・地域卓越特 任教授（广 380-8553 長野市若里 4-17-1 信州 大学工学部内 SASTec $2 \mathrm{~F}$ ラボ 6 ). 昭和 52 年 東北大学工学部卒業, 昭和 61 年神戸大学大学 院修了. 昭和 61 年 平成 13 年 : 三ツ星ベルト (株)，平成 14 年～現在：日信工業(株，平成 22 年 ～信州大学特任教授兼務. 専門は高分子, 複 合材料の構造と物性

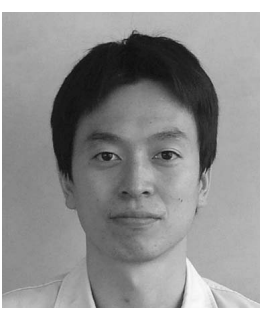

植木 宏之; 日信工業(株), 信州大学兼務：日 信工業(侏)開発本部・副研究員 ( $7386-8567$ 上 田市常田3-15-1 信州大学瀻維学部内 AREC15 研究室), 信州大学エキゾチック・ナノカーボ ンの創成と応用プロジェクト拠点・地域卓越 特任研究員（３80-8553 長野市若里 4-17-1 信州大学工学部内 SASTec $2 \mathrm{~F}$ ラボ 6 ). 平成 16 年 信州大学大学院工学系研究課博士前期 課程修了. 平成 16 年 現在:日信工業(侏), 平成 22 年 信州大学特任研究員兼務. 専門は高分 子，複合材料の構造と物性

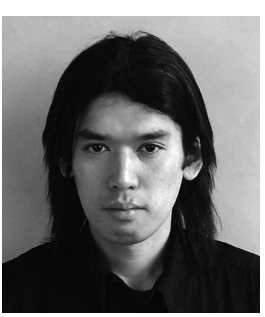

犬飼 茂樹 ; 日信工業(株)，信州大学兼務：日 信工業侏開発本部・副研究員 ( $\mathrm{T} 386-8567$ 上 田市常田3-15-1 信州大学繊維学部内 AREC15 研究室), 信州大学エキゾチック・ナノカーボ ンの創成と応用プロジェクト拠点・地域卓越 特任研究員 (₹ 380-8553 長野市若里 4-17-1 信州大学工学部内 SASTec $2 \mathrm{~F}$ ラボ 6 ). 平成 18 年愛知工業大学大学院工学研究科博士前期 課程修了. 平成 18 年 現在: 日信工業(侏), 平成 22 年〜信州大学特任研究員兼務. 専門は高分 子，複合材料の構造と物性

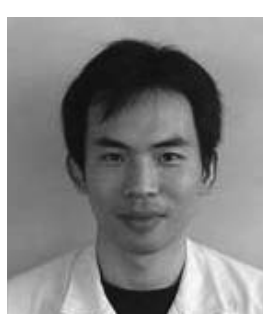

新原 健一; 日信工業(株), 信州大学兼務 : 日 信工業侏開発本部（衫386-8567 上田市常田315-1 信州大学繊維学部内 AREC15研究室), 信州大学エキゾチック・ナノカーボンの創成と 応用プロジェクト拠点・地域卓越特任研究員 （干 380-8553 長野市若里 4-17-1 信州大学工 学部内SASTec $2 \mathrm{~F}$ ラボ 6). 平成 15 年京都工 芸纎維大学繊維学部卒業, 平成 17 年京都工芸 纎維大学大学院工芸科学研究科修士課程修了, 平成 20 年京都工芸繊維大学大学院工芸科学研 究課博士課程修了. 博士 (工学) 取得. 平成 20 年 平成 21 年: NEDO 技術開発機構・大学発 事業創出実用化研究開発事業・研究員, 平成 21 年〜現在: 日信工業(侏), 平成 22 年一信州大学 地域卓越特任研究員兼務。専門は高分子，複 合材料の構造と物性

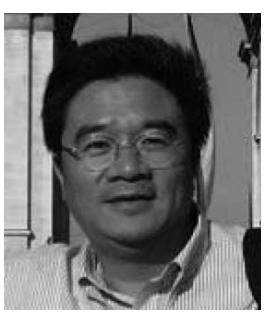

伊藤 正栄; シュルンベルジェ(侏)開発本部上 席研究員 (广 252-0206 相模原市中央区淵野辺 2-2-1)、メール：ito3@slb.com. 平成 4 年東京 大学大学院工学研究科修士課程修了. 平成 4 年〜現在：シュルンベルジェ(侏勤務。平成 4 〜 年：磁場を用いた石油探査機器の開発. 平 成 $8 \sim 16$ 年: 音波を用いた石油探査機器の開 発. 平成 16 年〜現在：CNTを用いた極限環境 用材料の研究開発. 専門は, 精密機械工学.

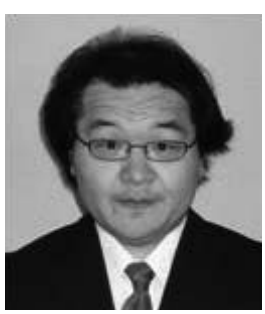

竹内 健司 ; 信州大学 ( $380-8553$ 長野市若 里 4-17-1) カーボン科学研究所准教授. 平成 8 年信州大学大学院博士課程了. 平成 8 年 成 20 年まで新光電気工業株式会社, 信州大学 工学部博士研究員, 昭和電工株式会社にそれ ぞれ在職した。現在，信州大学カーボン科学 研究所准教授, カーボンナノチューブの生成 と構造解析および応用に関する研究に従事. 工学博士.

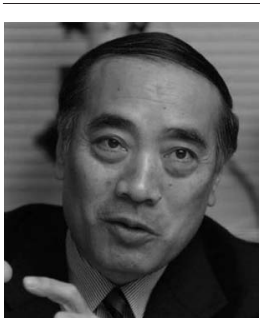

遠藤 守信; 信州大学 工学部電気電子工学 科教授、同カーボン科学研究所 所長 ( 380-8553 長野市若里 4-17-1). 昭和 46 年 信 州大学大学院工学研究科修士課程修了. 昭和 53 年 工学博士 (名古屋大学). 昭和 46 年 (侏) 日立製作所勤務。昭和 47 年 信州大学工学部 助手. 昭和 53 年 信州大学工学部助教授. 平 成 2 年 信州大学工学部教授 (現職). 平成 17 年 4 月 信州大学カーボン科学研究所所長（併 任) (現職)。専門は電気電子材料, エネルギ ーデバイス，ナノカーボンの生成と応用. 